\title{
KÖZÉP- ÉS KELET-EURÓPA ÁTALAKULÁSI, INTEGRÁCIÓS DILEMMÁI ÉS A MEZŐGAZDASÁG FENNTARTHATÓ FEJLESZTÉSE
}

\author{
(The dilemmas of integration in the transition of Central and Eastern \\ Europe and sustainable development in agriculture)
}

\section{SOMOGYI SÁNDOR}

\section{Bevezetö}

Berend akadémikus állapította meg egy újságcikkében, hogy Nyugat-Európában a gazdasági fejlödéshez kötődött a nemzetekké válás. Régiónkban - egy gazdaságilag fejletlen közegben - értelmiségiek hozták köztudatba a nemzeti eszméket, de úgy tünik keveset tettek a gazdasági felzárkózást, szervezettséget támogató eszmék terjesztéséért.

Így történhetett meg, hogy hallunk földrajzi, szellemi és politikai, de nem elegendöt a gazdasági Közép- és Kelet-Európáról (KKE), fejlesztési, környezeti problémáiról, életminőségéröl. Gazdasági lemaradásunk evidens. Mint minden kevésbé fejlett régióban a mezógazdaság és élelmiszertermelés itt is fontos része a nemzetgazdaságoknak. A fejlettebbeknél ezen ágazatok relatív fontossága már lecsökkent. Ugyanakkor szinten tartásuk magas támogatásokat igényel. Ezeknek a támogatásoknak köszönhetően világ. piaci versenypozícióik is jobbak.

Ilyen feltételek között KKE gazdaságáról, élelemtermeléséről, világpiaci pozíciókról nehéz átfogóan, elfogadható idődimenzióban gondolkodni és ugyanakkor a jövőbe tekinteni.

Itt történelmi hagyománya van a jobb teljesítményt gátló politikai, nemzeti, vallási és nem utolsó sorban gazdasági érdekütközéseknek.

A nagyhatalmi rendezések sem voltak egyértelmủen pozitívak. Az itt felmerüló problémákat saját érdekeik diktálta kritériumok alapján ítélték és oldották meg. Pl. az első világháború utáni igazságosnak vélt, nemzetállamokat formáló, határátszabások ebben a régióban megbontották az addig kialakult infrastrukturális és gazdasági kapcsolatokat, növelték a térség dezintegráltságát, kiélezték a nemzeti és egyéb ellentéteket és növekedett a térség gazdasági függősége a nagyhatalmaktól.

Az itteni népek elvesztek az érdekellentétek ,dajkálásában”, ahelyett, hogy készültek volna az integrációra, gazdasági függöségük csökkentésére. A szinergetikai hatások ennélfogva inkább negativak mint pozitívak. 
llyen feltételek, feszültségek mellett törvényszerüen jelentkezett a fejlesztési kényszer, a kevésbé fejlettekre jellemző természeti eröforrások terhére történő gazdálkodás és a környezetszennyezés. Felzárkózásunk a fejlettekhez emiatt kétszeres terhet jelent. Nem csak a fejlesztési kényszer szívja el a rendelkezésre álló eszközöket, de a környezetvédelmi beruházásokat is fedezni kell ahhoz, hogy a nemzetgazdaságok eurokonformmá váljanak.

\section{A régió társadalmi-gazdasági pozícióiról}

Ez a régió soha sem volt a kapitalista fejlödés folyamán a gazdasági fejlődés metacentruma és nem is válhatott azzá. Gazdaságilag a perifériához vagy félperifériához tartozott. A gazdasági következmények közismertek.

Régiónkra jellemzó, hogy a viszonyok a harmonizáció-diszharmonizáció és az integráció-dezintegráció skáláin mozognak. Érdekek, ellenérdekek véget nem érỏ harca zajlik szemeink elött és ennek vagyunk részesei.

A fejlettek nem ideológiai, hanem gazdasági okokból segitették az életképtelen tervgazdálkodási és hiánygazdálkodási modell bukását. Azt remélték - tekintettel az amerikai és európai piac telítettségére -, hogy rövid távon új piacot nyitnak maguknak, ami átlendítheti a recessziótól szenvedö gazdaságuk lendkerekét a holtponton.

Az események megmutatták, hogy a régióban, igazán mủködőképes - a fogyasztó társadalomra jellemző - piac nincs. Mélyreható változásokra van szuỉkség. Nincs elegendó tőke a piac motorjainak beindítására. Ugyanakkor a gyenge infrastruktúra, feszülttségek, bizonytalanság, a szocializmusból visszamaradt korai jóléti társadalmi viszonyok és demotiváltság nem nyújtanak megfelelö feltételeket a harmonikus fejlödésre.

Teljes társadalmi katarzisra és újraszerveződésre van szükség ahhoz, hogy a gazdasági átállás olyan gyors legyen mint azt sokan gondolták néhány éve, s elérjuk, hogy ne csak az olcsó munkaeró hanem a szervezettségünk is komparatív elónyt jelentsen.

Ellentétek, válságok, ellentétes folyamatok korát éljük. Sokszor felmerül a kérdés a nehezen áttekinthetö helyzetben, hogy van-e kiưt? Van.

Keresni kell az együttmüködést, közös érdekeket, célokat. Ez annál inkább is szükségszerüség, mert enélkül nem lehet megvalósitani a fenntartható fejlödést, ami viszont az itteni népek életminőségének is kulcskérdése.

\section{Közép-és Kelet-Európa gazdasági változásainak néhány jellemzője}

KKE; Lengyelország, Magyarország, Csehország, Szlovákia, Szlovénia, Románia, Bulgária, Litvánia, Lettország, Észtország, fontos földrajzi és demográfiai része Európának. (Célszerủ lett volna Jugoszláviát és Horvátországot is idesorolni, adataikat felhasználni. Vitathatatlanul komplettebb képet kaptunk volna, de érthető okokból integrálódásuk a régióval még nem igazán indult meg, és reális adatokhoz is nehéz hozzájutni.) 
Somogyi Sándor : Közép- és Kelet-Európa átalakulási, integrációs dilemmái és a mezőgazdaság fenntartható fejlesztése Tér és Társadalom 10. évf. 1996/4. 27-38. p.

TÉT $1996: 4$

Közép- és Kelet-Európa átalakulási, integrációs dilemmái...

29

\section{TÁBLÁZAT}

Közép-és Kelet-Európa és az EU összehasonlitása

(Comparision of Central and Eastern Europe with the EU)

\begin{tabular}{|c|c|c|c|c|c|c|c|}
\hline & \multirow{2}{*}{$\begin{array}{c}\text { Népesség } \\
\text { (millió) }\end{array}$} & \multicolumn{5}{|c|}{$\mathrm{Ter} u \mathrm{l}$ e $\mathrm{t}$} & \multirow{2}{*}{$\begin{array}{c}\text { GDP/cap } \\
\text { ECU }\end{array}$} \\
\hline & & $\begin{array}{c}\text { osszes } \\
\text { (millió ha) }\end{array}$ & $\begin{array}{c}\text { mezógazdasági } \\
\text { (millió ha) }\end{array}$ & $\%$ & \begin{tabular}{|c} 
megmüvelhetó \\
(millio ha)
\end{tabular} & $\%$ & \\
\hline Lengyelország & 38,5 & 31,3 & 18,6 & 59 & 14,3 & 0,37 & 1907 \\
\hline Magyarország & 10,3 & 9,3 & 6,1 & 66 & 4,7 & 0,46 & 3150 \\
\hline Csehország & 10,3 & 7,9 & 4,3 & 54 & 3,2 & 0,31 & 4586 \\
\hline Szlovákia & 5,3 & 4,9 & 2,4 & 49 & 1,5 & 0,28 & 1643 \\
\hline Szlovénia & 1,9 & 2,0 & 0,9 & 43 & 0,2 & 0,13 & 5018 \\
\hline Románia & 22,7 & 23,8 & 14,7 & 62 & 9,3 & 0,41 & 961 \\
\hline Bulgária & 8,5 & 11,1 & 6,2 & 55 & 4,0 & 0,48 & 1110 \\
\hline Litvánia & 3,8 & 6,5 & 3,5 & 54 & 2,3 & 0,62 & 657 \\
\hline Lettország. & 2,6 & 6,5 & 2,5 & 39 & 1,7 & 0,65 & 850 \\
\hline Észtország. & 1,6 & 4,5 & 1,4 & 31 & 1,0 & 0,63 & 938 \\
\hline KKE & 105,5 & 107,7 & 60,6 & 56 & 42,3 & 0,40 & 1786 \\
\hline EU 15 & 369,7 & 323,4 & 138,1 & 43 & 77,1 & 0.21 & 15972 \\
\hline $\mathrm{KKE} / \mathrm{EU}$ & $29 \%$ & $33 \%$ & $44 \%$ & & $55 \%$ & & $11 \%$ \\
\hline
\end{tabular}

KKE mint régió valamivel tỏbb mint egymillió négyzetkilométer, aminek 40\%-a mủvelhető. Valamivel tỏbb mint 100 milliós a lakosság létszáma, igy a lakosonkénti megmúvelhető terület 0,4 ha. Ez kedvezónek tekinthető, mert az EU lakosonkénti megmúvelhetỏ területének a kétszerese. Ugyanakkor a fejenkénti GDP csak 11\%-a az EU-beli GDP-nek, ami mutatja milyen szintủ a régió gazdasági lemaradása.

Az átalakulás ezekben az országokban a gazdasági tevékenység csỏkkenését okozta (2. táblázat). A GDP csôkkenése 1990-1992-ben általános jelenség volt. Évi átlagban $-6,2 \% ;-0,1 \%$; majd -3,5\%-ot tett ki. A javulás jelei 1993-tól mutatkoztak. Az 19911992-es árliberalizáció után volt az infláció a legmagasabb. Azóta csökken de lényegesen magasabb mint az EU-ban.

A költségvetési hiány, államadósság és munkanélküliség mutatói többé-kevésbé szintén kedvezötlenek (3. táblázat). 


\section{TÁBLÁZAT}

A GDP alakulása Közép-és Kelet-Európában az elözỏ év \%-ában (GDP in Central and Eastern Europe in per cent of the previous year)

\begin{tabular}{|l|r|r|r|r|r|c|}
\hline \multicolumn{1}{|c|}{ Ország } & 1990 & 1991 & 1992 & 1993 & 1994 & $1995^{*}$ \\
\hline Lengyelország & $-11,6$ & $-7,0$ & 2,6 & 3,8 & 5,0 & 5,0 \\
Magyarország & $-3,3$ & $-11,9$ & $-4,3$ & $-2,3$ & 2,0 & 0,3 \\
Csehország & $-1,2$ & $-14,2$ & $-6,4$ & $-0,9$ & 2,6 & 4,2 \\
Szlovákia & $-2,5$ & $-14,4$ & $-5,8$ & $-4,1$ & 4,8 & 4,5 \\
Szlovénia & $-4,7$ & 9,1 & $-5,4$ & 1,3 & 5,0 & 5,0 \\
Románia & $-5,6$ & $-12,9$ & $-10,1$ & 1,2 & 2,4 & 2,6 \\
Bulgária & $-9,1$ & $-11,7$ & $-5,8$ & $-4,2$ & 0,2 & 1,0 \\
Litvánia & $-3,3$ & $-13,1$ & $-34,0$ & $-27,1$ & 2,0 & 5,0 \\
Lettország & 2,9 & $-10,4$ & $-34,9$ & $-14,9$ & $-2,2$ & 5,0 \\
Észtország & $-6,5$ & $-8,1$ & $-14,3$ & $-8,2$ & 4,0 & 5,0 \\
KKE & $-6,2$ & $-10,1$ & $-3,5$ & 0,2 & 3,4 & 3,7 \\
EU 15 & 2,9 & 1,6 & 1,0 & $-0,5$ & 2,8 & 3,2 \\
\hline
\end{tabular}

*1995 becsult adatok

\section{TÁBLÁZAT}

Egyéb gazdasági mutatók Közép- és Kelet-Európában

- (Other economic indices in Central and Eastern Europe)

\begin{tabular}{|l|r|r|r|r|r|r|}
\hline \multirow{2}{*}{ Ország } & \multicolumn{2}{|c|}{$\begin{array}{c}\text { Infláció } \\
\text { \% }\end{array}$} & \multicolumn{2}{c|}{$\begin{array}{c}\text { Munkanélkuliség } \\
\%\end{array}$} & \multicolumn{2}{c|}{$\begin{array}{c}\text { Koltségvetési hiány a } \\
\text { GDP\%-ában }\end{array}$} \\
\cline { 2 - 7 } & 1994 & $1995^{*}$ & 1994 & $1995^{*}$ & 1994 & $1995^{*}$ \\
\hline Lengyelország & 32,2 & 25,0 & 16,1 & 16,0, & $-2,6$ & $-3,1$ \\
Magyarország & 19,1 & 28,0 & 10,5 & 12,0 & $-5,8$ & $-3,5$ \\
Csehország & 10,0 & 9,0 & 3,2 & 4,0 & 1,0 & - \\
Szlovákia & 13,4 & 12,0 & 14,8 & 15,0 & $-5,7$ & $-4,7$ \\
Szlovénia & 19,8 & 10,0 & 13,8 & 13,3 & $-0,2$ & $-0,2$ \\
Románia & 62,0 & 29,0 & 10,8 & 11,6 & $-4,4$ & $-3,3$ \\
Bulgária & 121,9 & 80,0 & 12,4 & 15,0 & $-6,7$ & $-6,0$ \\
Litvánia & 45,0 & 25,0 & 3,8 & 6,2 & $-2,0$ & $-2,0$ \\
Lettország & 25,0 & 20,0 & 6,5 & 10,0 & $-2,2$ & $-2,0$ \\
Észtország & 48,0 & 30,0 & 5,3 & 6,0 & $-2,2$ &. \\
EU 15 & 3,2 & 3,2 & 11,2 & 10,7 & $-5,5$ & $-4,5$ \\
\hline
\end{tabular}

*1995 becsült adatok 
Somogyi Sándor : Közép- és Kelet-Európa átalakulási, integrációs dilemmái és a mezőgazdaság fenntartható fejlesztése Tér és Társadalom 10. évf. 1996/4. 27-38. p.

TÉT 1996 - 4

Közép- és Kelet-Európa átalakulási, integrációs dilemmái...

31

\section{A mezőgazdaság szerepe Közép-és Kelet-Európában}

A régió országaiban a mezőgazdasági termelés viszonylag fontosabb szerepet játszik mint az EU-ban, tekintettel a mezỏgazdasági terület nagyságára és hozzájárulására a GDP-hez valamint foglalkoztatottsághoz. Ezt mutatják a 4. táblázat adatai is.

\section{TÁBLÁZAT}

A mezógazdaság szerepe Közép-és Kelet-Európában

(The role of agriculture in Central and Eastern Europe)

\begin{tabular}{|l|c|c|c|c|}
\hline \multirow{2}{*}{ Ország } & \multicolumn{4}{|c|}{ M e z ö $\mathrm{g}$ a z d a s á g i } \\
\cline { 2 - 5 } & $\begin{array}{c}\text { terúlet összter. } \\
\%\end{array}$ & $\begin{array}{c}\text { termelés GDP } \\
\%\end{array}$ & foglalk. összfogl.\% & $\begin{array}{c}\text { kivitel összkiv. } \\
\%\end{array}$ \\
\hline Lengyelország & 59,0 & 6,3 & 25,6 & 12,2 \\
Magyarország & 66,0 & 6,4 & 10,1 & 21,8 \\
Csehország & 54,0 & 3,3 & 5,6 & 7,7 \\
Szlovákia & 49,0 & 5,8 & 8,4 & 5,9 \\
Szlovénia & 43,0 & 4,9 & 10,7 & 4,7 \\
Románia & 62,0 & 20,2 & 35,2 & 6,8 \\
Bulgária & 55,0 & 10,0 & 21,2 & 20,7 \\
Litvánia & 54,0 & 11,0 & 22,4 & 12,8 \\
Lettország & 39,0 & 10,6 & 18,4 & \\
Észtország & 31,0 & 10,4 & 8,2 & 11,0 \\
KKE & 56,0 & 7,8 & 26,7 & - \\
EU 15 & 43,0 & 2,5 & 5,7 & 8,0 \\
\hline
\end{tabular}

Az is könnyen belátható, hogy a régión belül is a kevésbe fejlett országok gazdasága függ jobban a mezógazdaságtól. Az ilyen fejlettségi fok mellet az élelmiszer-kivitel is fontosabb szerepet játszik.

Sajnos, a kivitel elé az EU mind komolyabb akadályokat gördít. Említsük meg példaként az exporttámogatás csökkenésére vonatkozó követelményeket. Nyugaton az exporttámogatás magas volt, hazánkban és a régióban alacsonyabb. (Pl. a Visegrádi Négyek intervenciós árai 1994-ben az EU intervenciós szinthez viszonyítva a gabona esetében $51-71 \%$ volt, a marhahús esetében $30-44 \%$ és a tej esetében $28-65 \%$.) Tehát a nyugati termelök a támogatás csökkentése esetén is megörzik elönyüket.

A szubvenciók nemzeti szintre kerülésének következményei is súlyosabbak a kevésbé fejlettekre. Ha nemzeti szintre kerülnek, akkor a szegényebb országok több paraszt szubvencionálásával kell, hogy számoijanak, amit gazdaságilag nem bírnak el, mert a költségvetési hiányt sem növelhetik lényegesen. Ha viszont a termelöket nem támogatják, azok nem lesznek konkurensek és az állam elesik a kiviteli bevételektől.

Hasonló hatása van a szabványok, minőségi követelmények, kvóták előírásának is. Bizonyos értelemben „kötött kereskedelemróll” van szó. Végtermékek esetében a nyugati szabványoknak gyakran csak nyugatról behozott gépekkel lehet eleget tenni. A fejlettek a felszerelếs árait diktálva tulajdonképpen a beruházási szállításokkal már elvégzik az első lefollözést. 


\section{A mezõgazdaság alakulása Közép-és Kelet-Európában}

A mezógazdaság és élelmiszertermelés az előző pontban kidomboritott fontosságuk ellenére nagymértékben visszaestek az utolsó években. Az átalakulás első éveiben, azaz. 1989-től 1994-ig a mezőgazdaság hozzájảrulása GDP-hez megközelítőleg a felére csökkent,

A mezógazdasági termelés jellemzỏ alakulása nagymértékben az átalakulási folyamat hatásának tudható be. Az 5. táblázatból megállapitható, hogy Szlovénia és Románia kivételével a mezőgazdaság kibocsátása az 1989-es szint alá süllyedt.

\section{TÁBLÁZAT}

A mezőgazdaság brutıó kibocsátása Közép-és Kelet-Európa néhány országában

(Gross output of the agriculture in some countries of Central and Eastern Europe)

\begin{tabular}{|l|c|c|c|c|c|}
\hline \multirow{2}{*}{ Ország } & \multicolumn{5}{|c|}{ Bruttó kibocsátás $1989=100$} \\
\cline { 2 - 6 } & 1990 & 1991 & 1992 & 1993 & 1994 \\
\hline Lengyelország & 94,5 & 93,0 & 82,9 & 84,5 & 78,6 \\
Magyarország & 95,3 & 89,4 & 71,6 & 64,7 & 65,6 \\
Csehország & 97,7 & 89,0 & 78,3 & 76,4 & 72,2 \\
Szlovákia & 92,8 & 85,9 & 74,0 & 68,4 & 74,6 \\
Szlovénia & 104,2 & 101,1 & 90,5 & 98,0 & 118,2 \\
Románia & 97,1 & 97,9 & 84,9 & 95,7 & 101,0 \\
Bulgária & 94,0 & 93,7 & 82,5 & 67,5 & 70,2 \\
\hline
\end{tabular}

Természetesen, az elért eredményekre egyéb tényezök is kihatottak, pl.:

- időjárás,

- keresletcsökkenés,

- a fogyasztói támogatások csőkkenése,

- infláció,

- a termelói és fogyasztói árak közötti rés növekedése,

- piacresztés,

- az inputárak közelítése a magasabb világpiaci árakhoz, azaz az agrárolló kinyílása,

- az előzőekben felsorolt tényezők jővedelemcsőkkentő hatása,

- a privatizáció, átalakulás, átszervezés okozta bizonytalanság,

- a beruházások elmaradása stb.

\section{A mezőgazdaság üzemszerkezet átalakulása Közép- és Kelet-Európában}

A hatékonyságcsőkkenés fontos tényezője az üzemszerkezet átalakulása is. Az átalakulás, a tulajdonviszonyok rendezése és a piacgazdálkodással konform megoldások bevezetése elkerülhetetlen volt. Sajnos semmilyen tapasztalat nem létezett a tekintetben hogyan kell a tervgazdálkodási modellröl áttérni piacgazdálkodásira. Hogyan kell a 
Somogyi Sándor : Közép- és Kelet-Európa átalakulási, integrációs dilemmái és a mezőgazdaság fenntartható fejlesztése Tér és Társadalom 10. évf. 1996/4. 27-38. p.

szocialista társadalmi rendszerről áttérni kapitalizmusra. Ha az élelemtermelés átalakítása alaposabban tervezett és elökészített lett volna, akkor a reform társadalmi költségei is alacsonyabbak és a következmények kevésbé súlyosak lehettek volna. Arról nem is beszélve, hogy a helyzetet nehezíti a megfelelö gazdasági háttér nélkuli "koraszülött jóléti társadalom" lebontása is.

\section{TÁBLÁZAT}

Közép- és Kelet-Európa országainak mezógazdasági üzemstruktúrája és méretei

(Structure and size of the agricultural producers in Central and Eastern European countries)

\begin{tabular}{|l|c|c|c|c|c|c|}
\hline \multirow{2}{*}{ Ország } & \multicolumn{6}{|c|}{ A mezógazdasági terület \%-ában } \\
\cline { 2 - 7 } & \multicolumn{2}{|c|}{ szővetkezeti } & \multicolumn{2}{|c|}{ állami birtok } & \multicolumn{2}{c|}{ magángazdaság } \\
\cline { 2 - 7 } & korábbi & jelenlegi & korábbi & jelenlegi & korábbi & jelenlegi \\
\hline Lengyelország & 4 & 4 & 19 & 18 & 77 & 78 \\
Magyarország & 80 & 55 & 14 & 7 & 6 & 38 \\
Csehország & 61 & 48 & 38 & 3 & 1 & 49 \\
Szlovákia & 68 & 63 & 26 & 16 & 6 & 13 \\
Szlovénia & - & - & 8 & 7 & 92 & 93 \\
Románia & 61 & 35 & 14 & 14 & 25 & 51 \\
Bulgária & - & 41 & 90 & 40 & 10 & 19 \\
Litvánia & - & 35 & 91 & 1 & 9 & 64 \\
Lettország & - & 17 & 96 & 2 & 4 & 81 \\
Észtország & - & 33 & 96 & - & 4 & 67 \\
\hline & & Átlagnagyság hektárban & & & \\
\hline Lengyelország & 335 & 400 & 3140 & 2000 & 6,6 & 6,7 \\
Magyarország & 4179 & 1702 & 7138 & 1976 & 0,3 & 1,9 \\
Csehország & 2561 & 1430 & 6261 & 498 & 4,0 & 16,0 \\
Szlovákia & 2654 & 1665 & 5162 & 2455 & 0,3 & 1,0 \\
Szlovénia & - & - & 470 & 303 & 3,2 & 4,1 \\
Románia & 2374 & 170 & 5001 & 2002 & 1,5 & 1,8 \\
Bulgária & - & 750 & 13000 & 1100 & 0,4 & 0,6 \\
Litvánia & - & 450 & 2773 & 124 & 0,5 & 2,6 \\
Lettország & - & 706 & 3000 & 547 & 0,5 & 5,8 \\
Észtország & - & 567 & 3500 & - & 0,5 & 2,1 \\
\hline
\end{tabular}

Az átmenet problémáit talán az is okozta, hogy túl sokat foglalkoztak a tulajdonjog problémáival, ugyanakkor keveset a gazdaság szervezettségével. A két problémakör gyakran összemosódott. Nem vitatva a tulajdonjogi problémák megoldásának társadalmi szerepét, el kell gondolkodni a dezorganizációs hatások következményeiröl.

Az emlitett folyamatok (privatizáció, kárpótlás) hatása gazdaságilag erősen visszahúzó volt. Integrációk bomlottak fel, termékvertikumok zilálódtak szét, amelyek korábban tudtak bánni a piaccal. Megszünt a kivitel felszivó hatása ami növelte a termelést és a hatékonyságot. 
Sajnos a döntéshozók nem hallgatták meg az agrárágazatból élóket és szakértőit. Másik oldalról szükség is volt a tökeelvonásra, dezinvesztícióra, hiszen a rendszerváltásnak más pénzügyi forrása nem volt.

A következmények hosszú távra is súlyosak. A mezőgazdaság tőkeigényes, alacsony haszonkulcsú ágazat. Kiszorultunk hagyományos piacainkról, sőt saját piacunkon is a tőkeerős nyugati cégek. termékei terjednek, mert azok à kapacitások vásárlásával piacot is vásároltak.

Ezek a problémák is a fenntartható fejlesztés kibontakozását nehezítik.

\section{A fejlỏdést és jelenlegi ökológiai helyzetet befolyásoló korábbi jelenségek}

A fenyegetö környezeti problémák minden nap észlelhetök és a médiáknak köszönhetően közismertté válnak valamilyen formában. Ezek a problémák fokozatosan alakultak ki, ezért vissza kell tekinteni az elmúlt évtized néhány társadalmi - gazdasági jelenségére amelyek elősegítették a problémák kialakulását és utóhatásuk ma is érezhetô:

A FAO 1965-ben kezdte meg a felméréseket a világ élèlmezési helyzetéről és megállapitotta, hogy az emberiség fejlödésének legkritikusabb periódusa kezdetén áll. A FAO által szervezett élelmezési konferencia (1974) pesszimisztikus képet festett az élelmezés és emberiség jövőjéről. Megállapitották, hogy az emberiségnek csak 30\%-a táplálkozik jól vagy kielégitỏen, míg a többi gyengén, vagy éhezik.

Ilyen pesszimisztikus hangulatban neves tudósok és csoportok adtak lényegében véve Malthus-tipusú prognózisokat. (Emlékezzünk, hogy a szocialista államok teljesen elvetették Malthus tanait. Ezen prognózisok viszont, inkább dicsérik és finomítják Malthus meglátásait.)

Leontief és munkatársai elkészitették a világgazdaság és élelemtermelés növekedését kezelö inpout-output modellt. Lehetségesnek iteélték az élelemtermelés jelentös növekedését és kimutatták ennek környezetromboló, szennyezö következményeit is. A környezetszennyezésre úgy tekintettek mint a növekedés logikus és törvényszerủ következményére.

Medows és szerzőtársai 2050-re prognosztizálták a gazdasági növekedés okozta globális környezeti katasztrófät.

Mesarovich és Pestel ettól eltéiỏen regionális katasztrơfákat prognosztizáltak. Lényegében ezek a prognózisok is pesszimisták voltak.

Kahn és a Bariloche csoport mellett természetesen az orosz kutatók is vitatták az elörejelzések értékét. Fontos kidomborítani, hogy az oroszok elöször e prognózisok kritikájában ismerték el, hogy a fejlödés a vẹges fơldön csak véges lehet.

Mesarovich és Pestel munkái figyelmet érdemelnek, mert hangsúlyozták a regionálisan differenciált, de globálisan egyensúlyt teremtő fejlesztés szükségességét. Megítélésünk szerint ez a fejlettek kollektív egoizmusát érintette. A fejletlenek differenciáltabb, egyensúlyba hozó fejlesztése csak a fejlettek fogyasztásának visszafogásával történhetne meg.

Az élelmezési konferencia, Leontief elemzései és a prognózisok is odahatottak, hogy kialakultak azok a FAO akciók, melyeknek a lényege úgy is értékelhető, hogy: „mindent 
az élelemért". Ezen akciók hatására az élelem-termelés növekedése tényleg felgyorsult és meghaladta a demográfiai növekedést, de :

- nem csökkent az éhezỏk aránya a világon,

- az élelemtermelés növekedését 2-2,5-szer meghaladta a mezőgazdaság energiafogyasztásának növekedése,

- a drága technológiák gyorsabban növelték a mezỏgazdaság költségeit, mint a megnövekedett hozamok a jövedelmét.

Az ENSZ első környezetvédelmi világértekezlete (Stockholm, 1972), Lester Brown környezeti problémákat átfogóan kezelő monográfiája (Building a Sustainable Society, 1981) fontos kiindulópontja a környezeti problémák szélesebb körü ismertetésének.

Az alapvetỏ problémák megfogalmazása után sem állt be gyökeres változás. A Rio de Janeiróban 1992-ben tartott konferencia csak azt állapította meg, hogy a világ globális környezeti állapota tovább romlott. A gazdagok és szegények közötti szakadék tovább növekedett.

KKE mint régió a kevésbé fejlettekhez tartozik, kisebb anyagi javakkal és kiélezettebb környezeti problémákkal rendelkezik, aminek szintén van társadalmi elózménye. A lenini gondolkodás a kapitalizmus bukását jósolta, ugyanakkor a szocializmus fejlödési lehetóségeit határtalannak kiáltotta ki. Ennek alapján a volt Szovjetunió a fejlödést az általuk gazdagnak ítélt nyersanyagforrásokra alapozták és abban a meggyőződésben, hogy lehetőségeik kimeríthetetlenek extenzív fejlesztést végeztek. Sajnos ezt a felfogást terjesztették ki a fennhatóságuk alá került, valamivel fejlettebb KKE országokra is, aminek katasztrofális következményei különösen az élelemtermelésben (kivéve Magyarországot) ko̊zismertek.

Felvetỏdik a kérdés, hogy hol a kiứt a világ és régiónk számára?

A fejlettek és fejlődők közötti eltérések megkövetelnék a differenciált fejlődést. Olyan modell szükséges, amely a mennyiségi és minőségi fejlődést is felöleli. Teljesen érthetỏ, hogy a fejlődők, tehát régiónk esetében is a mennyiségi, míg a fejlettek esetében - a minőségi fejlödés kell, hogy elótérbe kerüljön. Az a fontos, hogy bármilyen is a fejlesztési súlypont a környezetkímélő technológiák és az erőforrás-takarékosság legyen az alapvető kritérium.

Az ökológiai problémák állandóan napirenden vannak. A fejletteknél a kívánt életminőség miatt. A fejlődőeknél a mennyiségi fejlödés szükségessége miatt. Tehát a fejlettek és fejletlenek problémái, céljai ebben a kérdésben is eltéróek.

A fejlettek fenn kivánják tartani gazdasági dinamikájukat és fogyasztási szintjüket. Ennek érdekében több lehetỏséget is kihasználnak:

Tisztább, energia- és anyagtakarékos technológiákat vezetnek be.

A környezetszennyezỏ technológiákat a szegény országokba telepitik.

Felhalmozásuk egy részét a környezetszennyezés ellen használják és megfelelő kutatásokba, fejlesztésekbe fektetik.

Szigorítják az elöirásokat.

A tudományos ismeretek jól átgondolt tálalásával, hitelfeltételekkel és minden más lehetséges módon úgy irányítják a kevésbé fejlettek fejlődésének szektorális arányait ahogy az nekik megfelel.

Előszeretettel mutatnak rá a hiányos erőforrás-gazdálkodás kővetkezményeire, intik a fejlődőeket az erőforrások kímélésére. Talán itt is igaz, hogy ,a tơrténelmet a győztesek 
írják", mert arról a fejlettek hallgatnak, hogy fejlôdésük korai fázisában ök is saját erőforrásaik terhére, most pedig a kevésbé fejlettek erőforrásainak térhere gazdálkodtak/gazdálkodnak. A felsoroltak még akkor is igazak, ha azt tapasztaljuk, hogy a fejletteknél is múködnek a különböző lobbyk és a fejlődés ott sem egyenes irányú.

A kevésbé fejłettek, tehát e régió környezeti problémái is másképpen jelentkeznek. Nem csak abban keresendök az okok, hogy a kevésbé fejlettek törvényszerúen a természeti eröforrások terhére gazdálkodnak. (A Samuelson-Nordhaus modell segítségével végzett elemzések egyértelmúen bizonyítják, hogy a fejlödő országok gazdasága hajlamos az eröforrások terhére gazdálkodni.) Ebben a régióban ezt a fejlesztési törvényszerüséget, Lenintöl errêelé ideológiai oknk is erósitették. Az említett ideológiai alláspontok is táplálták a nyersany ag és energia az az eröforrás-pocsékoló, alacsony hatékonyságú tömegtermelés fenntartását. Közismert, hogy Lenin tagadta a mezőgazdasági termelés közismert csökkenö hozamnövekedését is.

A régió országai az elözőekböl kifolyólag az átalakulás minden terhe mellett az ökológiai problémák, a fenntartható fejlesztés terheit is viselik.

\section{A fenntartható mezőgazdaság és a technológiai fejlesztés néhány problémája}

Nem az elmúlt periódusban fejlesztett technológiákban kell gondolkodni, amelyek a föld, nyersanyag és energia problémáit mellózték, hanem az olyan új technológiák bevezetésében, amelyek fơld, energia és nyersanyag takarékosságot igérnek. Emellett a hulladékok lebontását is segitik, tehát nem lineárisak, hanem a természetes folyamatokhoz hasonlóan cirkulárisak. Az ilyen technológiák kutatása viszont tỏkeigényes, komoly szellemi és menedzsment jellegü munkát igényel s erre megfeleló feltételeket csak a fejlettek tudnak biztosítani.

Az innovációk terjedési problémáival is számolni kell. Elvben az innovációdiffúzióval kapcsolatban további gyorsulással lehet számolni. Azt is tekintetbe kell azonban venni, hogy a recesszió miatt leromlott feltételek között az új igények diktálta követelmények mellett (környezetvédelem, erőforráskímélés, energiatakarékosság, hulladékmentesség, amelyek csak nagyobb tudásráfordítással és kreativitással oldhatók meg) nagyobb költségekkel kell számolni, ami a tökekorlátok miatt lelassíthatja a diffúziót. Különösen igaz lehet ez régiónkban (tehát hazánkban is), ahol a nagy befektetést igénylő kutatások elmaradtak a szükségletektól s az új megoldásokat kénytelenek lesznek megvásárolni. Ez a tőkekiáramlás félö, hogy tovább fogja a fejlett-fejletlen, gazdagszegény különbségeket növelni.

Ha a jelenlegi technológiák felhasználásából, vagy lecserélésébỏl indulunk ki könynyen beláthatóvá válik a további lemaradás veszélye. Egy fejlett ország esetében feltétlenul azzal kellene számolni, hogy fejlődésủk a használatban levỏ technológiára alapozva a logisztikus ,S" görbén már túlhaladta a progresszív növekedést és elérte a csökkenỏ hozadékkal jellemezhető növekedés fázisát.

Ugyanezeknek a technológiának bevezetése a növekedés érdekében egy kevésbé fejlett országban, a logisztikus „S” görbe progresszív növekedést jelző fázisát követné. 
Kézenfekvőnek tủnik, hogy az adott technológia mennyiségi fejlesztése, további terjesztése növekedést biztosit.

Feltételezhetö azonban, hogy a fejlettek új-minöségi technológiák bevezetésével új progresszív növekedési pályára állnak s akkor a fejlödők lemaradása minőségileg és mennyiségileg növekszik és könnyen érzékelhetö lesz.

Tehát a technikai - technológiai fejlesztés és a fenntarthatóság biztositása komoly dilemmák elé állitanak bennünket. Nem mindegy, hogy milyen stratégiát választunk, meglevő technológiákat, vagy új fejlesztéseket veszünk, fejlesztünk, vezetünk be, mert a lemaradás, vagy a felzárkózás a tét.

\section{Irodalom}

Agricultural Situation and Prospects in the Cent-ral and Eastern European Countries. European Comission Working Document.

Csáki Cs. (1995) Agricultural Transformation in Cent-ral and Eastern Europe and the Former USSR: Issues of Land Reform and Farm Restructuring, EAAE Seminar, Godollő.

Dunai P. (1995) Ázsia és a XXI. század, Népszabadság, december 16.

Luc Ferry (1994) Új rend: Az ökológia. Európa könyvkiadó. Budapest, 1994.

Láng I. (1995) A fenntartható fejlődés időszerü kérdései a mezögazdaságban, XXXVII. Georgikon Napok, Keszthely, 1995.

Somogyi Sándor: Evolucija poljoprivrednih kombinata u integratore agrobiznisa, Zbornik radova, Beograd, Centar Sava, 1995.

Somogyi Sándor: Development of Farm Sistem in Hungarian Agriculture, 44th Seminar of the EAAE, Thessalo-niki, 1995. october.

Somogyi Sándor: Az erőforrásmenedzsment néhány problémája a fejlödő országokban, XXVII. Georgikon Napok, Keszthely, 1995.

Somogyi S. - Dr. Novkovic N.: Sustainable Agricultural Develoment in Middle Europe and Hungary, 44th Seminar of the EAAE, Thessaloniki, 1995. oct.

Somogyi S. Aspects of the technical development of Yugoslav agriculture. International Journal of Technology Management, 8. 1-2. 0.

Leontief, W (1978) A világgazdaság jövöje. KSH, Budapest.

\section{THE DILEMMAS OF INTEGRATION IN THE TRANSITION OF CENTRAL AND EASTERN EUROPE AND SUSTAINABLE DEVELOPMENT IN AGRICULTURE}

\section{SÁNDOR SOMOGYI}

It is characteristic of Eastern Europe where we belong that the conditions swing between harmonisation and disharmonisation and integration-disintegration. Never-ending combats of interests and counter-interests are taking place before us and we cannot avoid being part of it.

In our region the need for forced development, economic activity to the detriment of the natural resources (that is typical of the less developed region) and environmental pollution inevitably appeared. Our keeping up with the developed countries is thus a 
double burden. It is not only the need for development that takes the resources that we have but also environmental investments have to be carried out in order to make the national economies Euro-conform.

In the countries of the region, agricultural production plays a relatively more important role than in the EU, considering the size of agricultural areas and the contribution of this sector to GDP and employment.

Ecological problems are continuously on the surface: in developed countries because of the splendid quality of life, in developing countries because of quantitative development and the necessity of transformation.

Transformation is presently taking place in the region, and a new phase of technicaltechnological development is gaining ground. We have to emphasise, however, that we cannot rely exclusively upon analogy - comparisons with the solutions of the past -, but we have to build on new development concepts.

We must not think in terms of technologies developed in the past period, which neglected the problems of land, raw material and energy, but we have to introduce new technologies which take the economical use of land, energy and raw materials into consideration. In addition, they help the breaking down of wastes, thus they are not linear but circular, similarly to the processes of Nature.

Translated by Zoltán Raffay

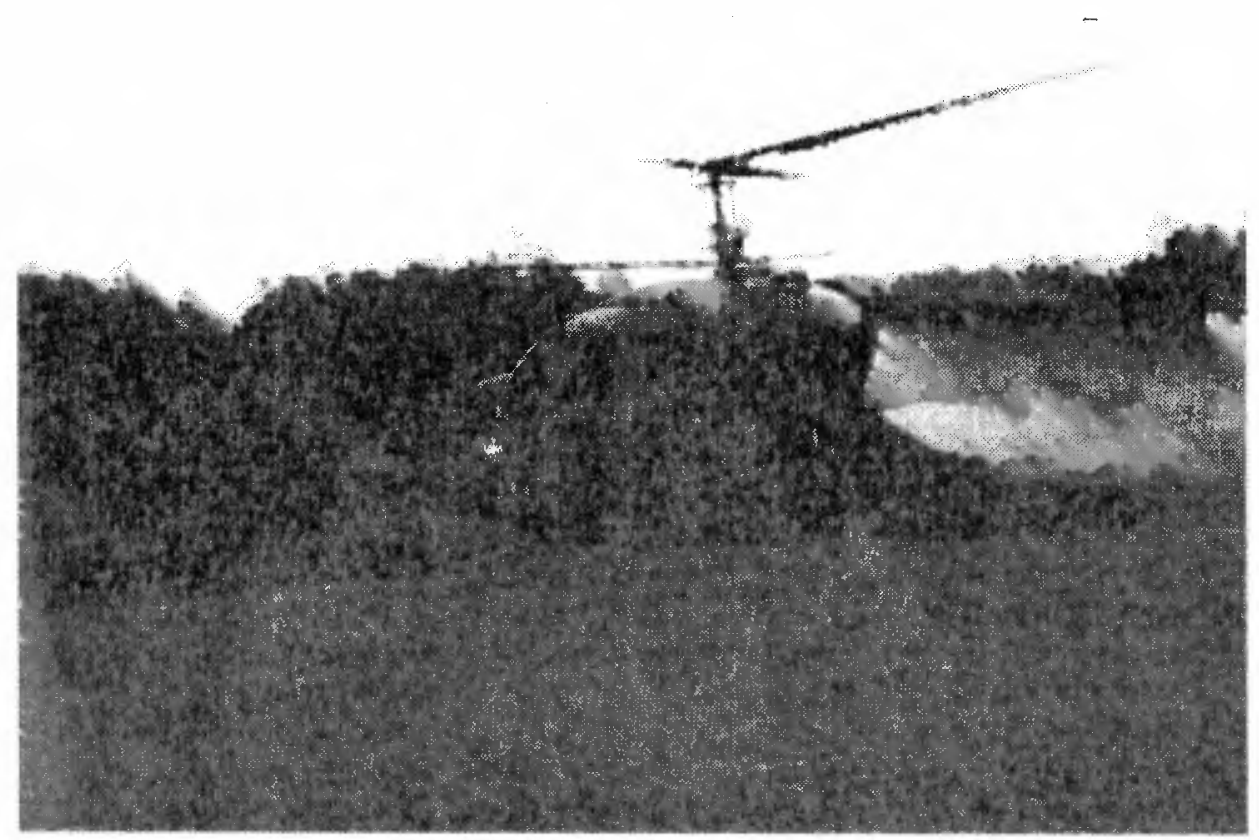

Repülőgépes permetezés (Pálfai L.) 